\title{
PANCASILA DAN NAHDLATUL ULAMA \\ DALAM BINGKAI NEGARA KESATUAN REPUBLIK INDONESIA (NKRI)
}

Oleh : Jamal Ghofir

\begin{abstract}
NU's acceptance of Pancasila was deeply and seriously thought NU. This made NU the first community organization to complete its acceptance of Pancasila. However, it has wrongly been used as an excuse to accuse NU for being accommodative in accepting Pancasila; NU acceptance of Pancasila is not based on its accommodative attitude, for it all based in deep thought and consideration. NU decision to leave practical politics and back to become a religious organization is also not an emotional attitude. Not only that NU was the first to receive Pancasila, this organization was also take it without any doubts. While Muhamadiyah came after it. They received Pancasila after the issuance of Law Number 8 Year 1985 on social organization.
\end{abstract}

Keywords: Islam, Nahdlatul Ulama, Pancasila.

\section{A. Pendahuluan}

Islam merupakan agama yang meletakan prinsip-prinsip kebenaran dan keadilan bagi setiap pemeluknya. Ia mencakup berbagai aspek kehidupan manusia serta upaya menghidupkan pemahaman dan pemikiran terhadap kejadian alam semesta beserta seluruh isinya. Dengan demikian, jika bimbingan wahyu yang datang kepada Nabi Muhammad SAW dipahami dengan pemahaman yang benar dan dikembangkan melalui pemikiran-pemikiran yang rasional, sudah tentulah akan tercipta keseimbangan antara ruhani dan jasmani manusia. Keseimbangan antara diri manusia dengan makhluk-makhluk yang ada di balik alam, binantang dan tumbuh-tumbuhan, serta keseimbangan antara manusia dengan alam sekitarnya (Karim, 2005 : 59).

Bimbingan serupa ini telah bermula dari para Rasul, apabila diteliti dengan seksama, merupakan rentetan yang berkembang menuju kehidupan ideal yang memungkinkan manusia dapat mengendalikan pelestarian alam sekitar. Dalam al-Qur'an terdapat berulang kali ayatayat yang memerintahkan kepada Nabi Muhammad SAW dan para pengikutnya agar menghadapkan tatapan wajahnya pada pegangan hidup yang menyerah pada kebenaran yang dinyatakan sebagai blue print dan rencana Allah SWT. Pada saat menciptakan alam dengan segala isinya yang merupakan kepastian yang tidak boleh diubah lagi.

“Maka hadapkanlah wajahmu dengan lurus kepada Agama Allah, tetaplah atas fitrah Allah yang telah menciptakan manusia menurut fitrah itu. Tidak ada 
perubahan dalam fitrah Allah (itulah agama yang lurus, tetapi kebanyakan manusia tidak mengetahuinya) “. Q. S. 30 (al-Ruum: 30).

Prinsip ini membimbing manusia kepada jalan lurus menuju kepada keseimbangan yang benar. Selain itu juga mampu menghidupkan manusia dari out of control yang memungkinkan manusia itu terlepas dari kebimbangan dan ketidak menentuan (Karim, 2005 : 60). Dengan demikian prinsip-prinsip ajaran wahyu ini menuntun manusia agar ia menyadari : kehidupan jasmani ini merupakan proyeksi dan manifestasi dari kehidupan ruhani, juga membimbing kehidupan nyata dan kehidupan metafisik yang memberikan lingkup dan jangkauan lebih luas dari hidup dan kehidupan manusia, agar memahami kekuatan yang ada pada dirinya, kekuatan yang ada pada alam semesta, dan kekuatan yang ada dibalik alam pikiran ini. Dengan demikian manusia memahami akan kenyataan-kenyataan hidup dan potensi alam serta memahami akan adanya aturan yang berlaku bagi alam semesta dan pada dirinya (Ridha, $1373 \mathrm{H}:$ 244-245).

Prinsip-prinsip ajaran Islam sangat kokoh yang menggabungkan antara kekuatan ruhani dan kekuatan jasmani, serta menggabungkan pula kehidupan alam ghaib dan alam nyata. Apabila hal tersbeut diletakan pada prinsip soverenitas yang tertinggi pada Maha Pencipta, maka keberadaan manusia tidak berhak untuk menyatakan dirinya mempunyai soverenitas di permukaan bumi sebagaimana di jelaskan dalam al-Qur'an.

Dan Jikalau Tuhanmu menghendaki, tentulah beriman semua orang yang di muka bumi seluruhnya. Maka Apakah kamu (hendak) memaksa manusia supaya mereka menjadi orang-orang yang beriman semuanya?

Dan tidak ada seorangpun akan beriman kecuali dengan izin Allah; dan Allah menimpakan kemurkaan kepada orang-orang yang tidak mempergunakan akalnya. Katakanlah: "Perhatikanlah apa yaag ada di langit dan di bumi. tidaklah bermanfaat tanda kekuasaan Allah dan Rasul-Rasul yang memberi peringatan bagi orang-orang yang tidak beriman".

Islam telah memberikan kemerdekaan kepada seluruh manusia, dalam pengertian setiap manusia memiliki nilai yang sama dihadapan Allah SWT. Islam juga senantiasa meletakkan prinsip-prisip persaudaraan diantara sesama manusia. Keberdaan manusia yang satu dengan yang lainnya memiliki hak dan kuwajiban yang sama, memilik derajat yang sama pula. Hal ini telah ditegaskan dalam al-Qur'an.

Orang-orang beriman itu Sesungguhnya bersaudara. sebab itu damaikanlah (perbaikilah hubungan) antara kedua saudaramu itu dan takutlah terhadap Allah, supaya kamu mendapat rahmat.

Hai orang-orang yang beriman, janganlah sekumpulan orang laki-laki merendahkan kumpulan yang lain, boleh jadi yang ditertawakan itu lebih baik dari mereka. dan 
jangan pula sekumpulan perempuan merendahkan kumpulan lainnya, boleh jadi yang direndahkan itu lebih baik. dan janganlah suka mencela dirimu sendiri dan jangan memanggil dengan gelaran yang mengandung ejekan. seburuk-buruk panggilan adalah (panggilan) yang buruk sesudah iman dan barangsiapa yang tidak bertobat, Maka mereka Itulah orang-orang yang zalim.

Hai orang-orang yang beriman, jauhilah kebanyakan purba-sangka (kecurigaan), Karena sebagian dari purba-sangka itu dosa. dan janganlah mencari-cari keburukan orang dan janganlah menggunjingkan satu sama lain. Adakah seorang diantara kamu yang suka memakan daging saudaranya yang sudah mati? Maka tentulah kamu merasa jijik kepadanya. dan bertakwalah kepada Allah. Sesungguhnya Allah Maha Penerima Taubat lagi Maha Penyayang.

Hai manusia, Sesungguhnya kami menciptakan kamu dari seorang laki-laki dan seorang perempuan dan menjadikan kamu berbangsa - bangsa dan bersuku-suku supaya kamu saling kenal-mengenal. Sesungguhnya orang yang paling mulia diantara kamu disisi Allah ialah orang yang paling taqwa diantara kamu. Sesungguhnya Allah Maha mengetahui lagi Maha Mengenal. Q. S. 49 (al-Hujurat : 10-13).

Inilah kemerdekaan yang diberikan oleh Allah SWT kepada manusia dalam hubungannya dengan sesama umat manusia dan Allah SWT tidak memberikan kemerdekaan bagi manusia terkait hubungannya dengan alam. Akan tetapi Allah SWT memberikan anugrah akal fikiran guna di manfaatkan untuk menjinakkan alam semesta beserta isinya melalui hukum-hukumnya. Sebagaimana dijelaskan dalam al-Qur'an.

Kami akan memperlihatkan kepada mereka tanda-tanda (kekuasaan) kami di segala wilayah bumi dan pada diri mereka sendiri, hingga jelas bagi mereka bahwa Al Quran itu adalah benar. Tiadakah cukup bahwa Sesungguhnya Tuhanmu menjadi saksi atas segala sesuatu? Q. S. 41 (Fushsilat : 53).

Oleh karena itulah, manusia tidak boleh secara bebas melakukan pengaturan menurut pola-pola pemikirannya, tetapi manusia harus memahami akan kekuasaan Allah SWT yang terdapat di alam semesta ini serta berusaha berbuat sesuai dengan kekuasaan tersebut.

\section{a. Ajaran Kemerdekaan dalam Islam}

Islam sebagai agama diletakan pada ajaran akidah dan ibadah. Akidah merupakan suatu basis yang memberikan corak dan tingkah laku dalam perbuatan seseorang. Manusia diajaknya kepada pemikiran yang fitrah dan diterima oleh pemikiran yang merdeka, terlepas dari belenggu dan paksaan darimanapun. Dengan pemikiran yang merdeka manusia dapat berfikir bebas dan mengembangkan pikiran untuk menemukan tata nilai baik dan buruk, sehingga manusia dapat menentukan dan menyusun aturan-aturan kemasyarakatan yang mengarah kepada kemajuan. Hal ini merupakan dorongan yang sangat kuat bagi manusia guna mefungsikan potensi ruhani dan jasmani dalam melestarikan kedudukan manusia di 
jagat raya (Karim, 2005 : 70-71). Prinsip-prinsip inilah yang menjadi penyemangat umat Islam dalam memadukan pemikiran, memperkuaat persatuan, dan menggerakan kemerdekan sebagai sarat yang mutlak dalam upaya terwujudnya kemaslahatan dalam kehidupan.

Kemerdekaan yang didapatkan oleh rakyat Indonesia bukanlah semata-mata dari perjuangan yang diperjuangankan selama ini. Namun kemerdekaan yang dicapai merupakan limpahan rahmat yang diberikan oleh Allah SWT. Hal ini terbukti dengan adanya pembukaan Undang-Undang Dasar 1945. Dengan melihat kondisi keragaman di Indonesia, umat Islam telah puasa dengan dicantumkannya "Ketuhanan Yang Maha Esa dalam Undang-Undang Dasar 1945. Meskipun dengan semangat toleransi yang tinggi umat Islam merelakan penghapusan "tujuh kata" pada sila yang pertama sebagaimana yang termuat dalam Piagam Jakarta (Boland, 1971 : 27). Dengan demikian umat Islam telah memahami pentingnya persatuan dan kesatuan sebagai sarat mutlak terbinanya kerukunan dalam menjalani kehidupan sebagaimana Rasulullah SAW telah membangun masyarakat yang madani dengan Konstitusi Piagam Madinah. Ajaran Islam telah menegaskan bahwasanya mementingkan kemaslahatan umum seyogyanya lebih didahulukan dari pada kemaslahatan pribadi atau golongan.

Kemaslahatan umum dalam hal ini adalah kesadaran dalam menegakkan berdirinya Negara Kesatuan Republik Indonesia (NKRI) yang berdaulat berdasarkan Ketuhanan Yang Maha Esa, Kemanusiaan yang adil dan beradab, Persatuan Indonesia, permusyawaratan yang dibimbing oleh hikmah kebijaksanaan dan Keadilan social yang merata bagi seluruh Indonesia. Prinsip-prinsip tersebut merupakan ajaran Islam yang terkandung dalam kitab suci al-Qur'an dan Sunnah. Sebagai landasan yang kuat bagi terlaksananya ajaran-ajaran Islam. Pemikiran tersebut merupakan refleksi pemikiran yang berintraksi langsung dan berpegang teguh pada al-Qur'an dan Sunnah. Dengan landasan pemikiran tersebut terbentuklah Negara Kesatuan Republik Indonesia yang berdaulat, mempunyai wawasan dan strategi yang berkarakter bagi percaturan politik nasional maupun global.

Perjuangan kemerdekaan merupakan hak setiap bangsa, oleh karena itulah penjajahan harus dihapuskan dari muka bumi ini. Demikianlah pemikiran bangsa Indnoesia dalam menegakkan dan melakukan pengawalan terhadap kemerdekaan yang telah diperjuangkan sampai mengorbankan banyak nyawa anak bangsa. Apabila mau berfikir lebih mendalam dan berfikir secara falsafi, dapatlah bahwa pemikiran tersebut adalah pemikiran yang murni. Karena keberadaan manusia diciptakan sebagai khalifah di muka bumi ini, memiliki tanggugjwab yang besar dalam melestarikan ciptaan Allah SWT. Dan yang membimbing 
dalam upaya pelestariaan tersebut hanyalah Sang Pencipta. Karena hal tersebut sebagai modal dasar dalam upaya merealisasikan perjuangan kemerdekaan yang berdasarkan Pancasila.

Dari pemaparan di atas telah memberikan penegasan, bahwasanya prinsip-prinsip ajaran Islam yang telah memberikan semangat kejuangan dalam meraih kemerdekaan Indonesai tidaklah berasal dari ruang yang hampa. Umat Islam bersama dengan pergerakanpergerakan nasional, bahu membahu guna mengusir para kolonilaisme dan imperialisme, dimana prinsip-prinsipnya yang tidak sejalan dan bertentangan dengan ajaran Islam. Guna memperkuat gagasan tersebut, penggalian dari kenyataan sejarah Bumi Nusantara dari sejak zaman Majapahit pada prinsipnya kemerdekaan tersebut telah dimiliki dan diperjuangkan oleh bangsa Indonesia. Kalau ditinjau dari kenyataan sejarah secara prinsip dapatlah dikatakan bahwa umat Islam telah melakukan asas-asas yang penting bagi dasar Negara, terbukti sebagian prinsip-prinsip al-Qur'an tertuang dalam Pancasila.

Walaupun orang Islam dengan suka rela menghapus "tujuh kata" pada sila yang pertama dari Pancasila, tiada lain hanyalah untuk memelihara keutuhan dan persatuan bangsa, dengan kesadaran bahwasanya bersatu merupakan hal yang wajib didahulukan. Disinilah letak ketinggian moralitas umat Islam dalam memperjuangkan mempertahankan kemerdekaan Indonesia.

\section{b. Faktor Pendorong Umat Islam Mencapi kemerdekaan}

Kemerdekan Indonesia yang telah dicapai merupakan hasil dari perjuangan yang sangat panjang, melibatkan seluruh potensi yang ada di dalam masyarakat. Potensi penentu dalam kancah perjuangan meraih kemerdekaan terdiri dari berbagai penganut agama dan yang terbanyak adalah umat Islam. Sebagai tindak lanjut dalam pengembangan kemerdekaan di masa depan, sudah tentu akan banyak ditentukan oleh umat Islam itu. Islam berpangkal pada penekanan kemerdekaan yang utuh dan berimbang diantara kemerdekaan individu dan masyarakat, kemerdekaan manusia dengan lingkungan, kemerdekaan ruhani dan jasmani. Ajaran kemerdekaan yang berkenaan dengan keseimbangan diri manusia dan Maha Pencipta adalah dorongan yang sangat kuat dalam mendasari kekuatan yang ada. Ajaran inilah yang dinamakan dengan ajaran tauhid.

Sebagaimana dijelaskan oleh Prof. Dr. M. Abdul Karim., M. A., M. A dalam bukunya Islam dan Kemerdekaan Indonesia, Membongkar Marjinalisasi Peranan Islam dalam Perjuangan Kemerdekaan RI. Ia menegaskan bahwasanya keberhasilan Umat Islam dalam meraih kemerdekaan didorong oleh beberapa factor. Adapun factor-faktor tersebut yaitu : 


\section{Faktor Idiologi}

Ajaran keimanan yang tertuang dalam kaum muslim di Indonesia merupakan akidah yang kokoh, kuat, dan berakar dalam jiwa mereka. Di dalamnya terkandung ajaran yang meletakkan kekuatan pada Maha Pencipta manusia serta alam dan isinya, terpancarlah keyakinan bulat akan kekuatan yang ada pada manusia merupakan amanah yang harus dilakukan sesuai dengan kehendak-Nya. Sikap serupa itu membuahkan gerak, tingkah laku, dan perbuatan yang rela berkorban untuk menjunjung tinggi kebenaran. Hal tersebut merupakan factor tercapainya perjuangan kemerdekaan Indonesia.

\section{Faktor Politik}

Ajaran Montesquieu, Voltaire, dan Jean Jacques Rousseau membuahkan " Revolusi Perancis" dan menyebabkan rasa cinta tanah air Les enfants de la Patri. Ajaran itu banyak dibaca oleh pemuda bangsa Indonesia yang sedang belajar, sehingga menimbulkan minat untuk mendobrak kekuasaan yang membelit bangsa Indonesia, sehingga menimbulkan pergerakan-pergerakan dikalangan kaum muslim, hanya saja niat ini belum dapat dicetuskan menunggu saat-saat yang baik sebagai peluang, ditambah dengan semangat patriotis pahlawan-pahlawan kemerdekaan seperti Imam Bonjol, Diponegoro, dan sebagainya yang ikt mendobrak kekuasaan Belanda untuk mencapai kemerdekaan Indonesia (Ma'arif, $1985: 1-7)$.

\section{Faktor Ekonomi}

Keberadaan Indonesia yang berada di antara dua benua, Asia-Australia dan dua samudra yaitu samudra India dan Samudra Pasifik. Sehingga dalam strategi ekonomi merupakan lintas perdagangan yang sangat menguntungkan. Tanahnya yang subur dibelah oleh sungai-sungai dan gunung-gunung merupakan sumber kekuatan ekonomi. Juga barang-barang tambang yang tersebar di Nusantara, merupakan kekuatan yang mendukung bagi terciptanya kemerdekaan (Servis, $1962: 7-8$ ).

\section{Faktor Sosial}

Indonesia terdiri dari aneka ragam suku dan agama yang didukung oleh aneka ragam susunan kemasyarakatan, tata nilai yang turut serta memberikan alternatife yang sangat banyak bagi pembentukkan nilai-nilai kemasyarakatan. Dengan demikian nilai diambil dari berbagai macam nilai yang tumbuh dalam tata kemasyarakatan, menyebabkan kematangan dan memberikan pandangan yang luas bagi kematangan pikiran, sehingga dalam mewujudkan rumusan-rumusan dalam perjuangan mencapai kemerdekaan, merupakan rumusan yang didukung oleh kekuatan sosial. Oleh karene 
itu, saat menjelang kemerdekaan betapapun juga ada usaha-usaha untuk memecah belah rumusan-rumusan yang terpadu itu mengalami kegagalan-kegagalan. Aneka ragam hukum adat yang tumbuh di berbagai tanah air, menggambarkan adanya asasasas persamaan yang memancarkan jiwa persatuan. Walupun mereka berbeda dalam keyakinan. Tetapi dalam kebiasaan hidup sehari-hari dalam upacara-upacara adat masih menampakkan asas persamaan yang memudahkan mereka untuk merumuskan dalam konsep-konsep persatuan.

\section{Faktor Budaya}

Hampir seluruh hasil budaya yang berada di Indonesia dapat dipertahankan pada budaya yang terpancar dan kebudayaan yang pernah dipersatukan oleh Majapahit dan inilah yang diyakini oleh bangsa Indonesia sebagai budaya asli yang dapat mempersatukan seluruh yang tersebar di tanah air (Murtopo, 1978 : 16-44).

\section{B. Perjalanan Panjang Idiologi Negara Indonesia}

Sejak Pancasila ditetapkan oleh Majelis Permusyawaratan Rakyat (MPR) sebagai satu-satunya asas bagi seluruh oerganisasi sosial dan politik yang dituangkan dalam ketetapan MPR No. II/MPR/1983 tentang Garis-Garis Besar Haluan Negara (GBHN). Ini merupakan keputusan politis yang paling gemilang bagi bangsa dan Negara Indonesia sejak kemerdekaan. Sebelumnya menjelang kemerdekaan, Pancasila diterima sebagai dasar Negara Indonesia setelah melalui perdebatan yang sangat sengit, terutama antara golongan nasionalis dan Islam (Pranarka, 1985 :25-54) dan menjadi diskusi yang sangat hangat setelah Indonesia merdeka. Dengan ketetapan itu, maka seluruh organisasi sosial dan politik harus menyesuaikan diri. Nahdlatul Ulama (untuk selanjutnya ditulis NU) menerima Pancasila sebagai asas organisasi pada Muktamar ke-27 bulan Desember 1984 di Situbondo Jawa Timur (Sitompul, $2010: 1$ ).

Pancasila adalah warisan dari jenius Nusantara. Sesuai dengan karaktreistik lingkungan alamnya, sebagai negeri lautan yang ditaburi pulau-pulau (archipelago). Istilah yang lazim dipakai untuk melukiskan Negara Indonesia adalah “ Negara kepulauan”, yang mengandung daratan. Menarik, bahwa Soekarno pernah menyebut Negara Indonesia sebagai "Negara lautan yang ditaburi pulau-pulau". Oleh karena itulah, Indonesia lebih sesuai dengan istilah archipelago " kekuasaan lautan". Jenius Nusantara juga merefleksikan sifat lautan. Sifat lautan adalah menyerap dan membersihkan, menyerap tanpa mengotori lingkuangan. Sifat lautan juga dalam keluasannya, mampu menampung segala keragaman jenis dan ukuran (Latif, $2011: 2$ ). 
Dijelaskan juga oleh Yudhi Latif bahwa Indonesia merupakan Negara kepulauan terbesar di dunia, yang membujur di titik strategi persilangan antar benua dan antar samudara, dengan daya tarik kekayaan sumber alam yang berlimpah. Keberadaan Indonesia sejak lama telah menjadi titik temu penjelajahan bahari yang membawa pelbagai arus peradaban. Maka, jadilah Nusantara sebagai taman sari peradaban dunia. Nusantara juga merefleksikan saifat tanahnya yang subur, terutama akibat debu muntahan deretan pegunungan vulkanik. Keberadaan tanah yang subur, memudahkan segala bentuk tanaman tumbuh dengan suburnya. Nusantara juga sanggup menerima dan menumbuhkan apapun budaya dan idiologi yang masuk, sejauh dapat dicerna oleh sistem sosial dan tata nilai yang telah ada.

Etos pertanian masyarakat Nusantara bersifat relegius dan gotong-royong, dalam rangka meringankan penggarapan lahan secara bersama-sama. Sifat relegius dan sensitivitas kekeluargaan juga memijarkan daya-daya etis dan estetis yang kuat. Maka jadilah Nusantara sebagai pusat persemaian dan penyerbukan silang budaya yang mengembangkan pelbagai corak kebudayaan yang lebih banyak dibandingkan dengan kawasan Asia manapun (Oppenheimer, 2010 : xxvii).

Penindaan ekonomi poltik oleh kolonialisme-kapitalisme memang banyak menggerus sifat-sifat kemakmuran, cosmopolitan, relegius, toleransi, dan kekeluargaan dari tanah air ini. Di sisi lain kolonialisme-kapitalisme juga mengandung kontradiksi-kontradiksi internal tersendiri yang membawa unsur-unsur emansipasi baru, seperti humanisme, prikebangsaan, demokrasi, dan keadilan yang dapat memperkuat karakter bangsa. Persenyawaan antara anasir karakter asal yang mengendap laten dalam jiwa penduduk dan visi emansipasi baru itu diidealisasikan oleh para pendiri bangsa sebagai sumber jati diri, dasar falsafah, dan pandangan hidup bersama.

Ketika Dr. Radjiman Wediodiningrat selaku Ketua Badan Penyelidik Usaha Persiapan Kemerdekaan (BPUPKI), pada tanggal 29 Mei 1945 meminta kepada sidang guna mengemukakan dasar Negara Indonesia merdeka. Permintaan tersebut menjadikan rangsangan guna memutar kembali ingatan para pendiri bangsa, hal ini menjadikan semangat bagi mereka guna menggali kembali kekayaan yang dimiliki oleh Nusantara baik kekayaan kerohaniaan, kepribadian, dan wawasan kebangsaan yang telah terpendam dalam lumpur sejarah perjalanan bangsa Indonesia.

Penggalian sejarah yang lama terpendam membuahkan hasil prinsip-prinsip dasar Negara Indonesia merdeka yang dirumuskan oleh para pendiri bangsa dan tidaklah dipungut dari udara. Melainkan prinsip-prinsip tersebut digali dari bumi sejarah keindonesiaan yang mengalami lika-liku perjuangan yang panjang. Penggalian falsafah bangsa tidak berhenti 
sampai zaman gelap penjajahan, akan tetapi penggalian tersebut menerobos jauh kebelakang hingga jauh ke zaman kejayaan Nusantara. Para pendiri bangsa senantiasa memikirkan dan merasakan apa yang dialami bangsanya selama masa penjajahan dan mengingat apa saja yang pernah mereka perjuangkan dan impikan sebagai sumber pembebasan, kebahagiaan, dan identitas bersama (Latif, $2011: 4-5$ ).

\section{NU dan Asas Tunggal Yang Final}

Penerimaan NU atas Pancasila benar-benar dipikirkan oleh NU secara matang dan mendalam. NU adalah organisasi kemasyarakatan yang pertama menuntaskan penerimaannya atas Pancasila. Kendati demikian, hal itu bukanlah alasan untuk menuduh bahwa penerimaan itu karena ia bersikap akomodatif, dan juga tidak benar bahwa kembalinya NU menjadi organisasi keagamaan atau meninggalkan politik praktis sebagai sikap yang emosional (Karim, 1983 : 90-91). NU bukan hanya yang pertama menerima, melainkan juga yang paling mudah menerima Pancasila. Muhamadiyah menerima pancasila setelah terbitnya UndangUndang Nomor 8 Tahun 1985 tentang organisasi kemasyarakatan (Harun, 1986 : 33-69).

Pertemuan ulama yang menentukan masa depan NU berlangsung di Surabaya pada tanggal 1 Mei 1982, kota yang memiliki arti historis bagi NU, karena di kota inilah NU didirikan (Irsyam, 1984 : 123). Dengan tindakan itu mereka menunjukkan kembali kapasitasnya sebagai ulama. Disadari bahwa prosesnya akan rumit bila mengikuti AD/ART, padahal NU membutuhkan tindakan yang segera, karena itulah para ulama melalui rais 'Am Ali Maksum, tampil dengan mengandalkan hukum Islam. Tindakan para ulama yang demikian itu, menjadikan pertentangan dikalangan intern NU semakin terbuka, sehingga membutuhkan penyelesaikan segera. Idham Chalid yang telah mencabut pengunduran dirinya karena diprotes oleh pengurus wilayah, menghimpun kekuatan dan menginginkan segera diadakan Muktamar. Sedangkan para ulama lebih memperhatikan perlunya diadakan Munas (Musyawarah Nasional Alim Ulama NU) terlebih dahulu yang akan menjadi rekomendasi bagi Muktamar NU XXVII. Sementara itu, asas Pancasila sebagai isu nasional juga harus mendapat perhatian NU. Karena pertentangan sudah terbuka, masa depan NU tidak lagi ditentukan oleh dirinya sendiri, tetapai juga oleh pemerintah (kepada pihak mana izin mengadakan Muktamar/Munas diberikan) dan bagaimana NU menanggapi asas Pancasila sebagai isu nasional (Sitompul, 2010 : 167-168).

Pihak ulama berhasil memenangkan perhatian pemerintah yang terbukti dengan mendapatkan green light untuk menyelenggrakan Munas. Kemudian Munas diselenggarakan di Pondok Pesantren Salafiyah Syafi'iyah Sukorejo Situbondo. Pesantren yang dipimpin dan diasuh oleh KH. As'ad Syamsul Arifin pada bulan desember tahun 1983. Sedangkan 
kelompok politisi (Idham Chalid dan kawan-kawan ) juga melakukan pendekatan kepada pemerintah. Akan tetapi. Sebagaimana di tegskan oleh pihak ulama, bahwasanya permasalahan asas tunggal Pancasila telah dibicarakan kepada pemerintah, ketika KH. As'ad Syamsul Arifin menemui presiden Suharto sebelum Munas:

Kiai haji As'ad Syamsul Arifin sesepuh Syuriah NU dari Jawa Timur belum lama berselang telah lama diterima oleh Presiden Soeharto dalam pertemuan khusus. Dalam pertemuan itu KH. As'ad Syamsul Arifin telah menegaskan pendirian sebagaian besar ulama dan umat Islam Indonesia bahwa mereka menerima Pancasila hukumnya adalah wajib.... KH. As'ad juga menyatakan pendapatnya tentang perlunya diadakan suatu musyawarah nasional alim ulama untuk meratakan pendirian itu. Munas tersebut antara lain akan memasyarakatan sikap yang diutarakan KH. As'ad dan sekaligus dilihat kemungkinan perubahan Anggaran Dasar NU sebagai konsekuensi dari pernyataan tersebut...pernyataan di hadapan Presiden Soeharto itu adalah sikap dan pendirian KH. As'ad dan bukan sama sekali permintaan presiden (Sitompul, 2010168 169).

Pernyataan yang dikemukaan oleh KH. As'ad bukanlah sikap yang mendahului Munas atau takut menghadapi tekanan. Untuk memahami hal tersebut tentulah harus memahami ranah kehidupan dalam organisasi Nahdlatul Ulama. Pertama, keberadaan ulama dan pesantrennya memiliki kewibawaan yang sangat kuat dimata umat. Keberadaan para ulama yang menjadi inisiator dan konseptor keputusan Muktamar Situbondo adalah ulama yang memiliki basis umat dan memiliki kewibawaan serta pesantren yang besar. Diantara ulama tersebut adalah Kiai Ali Maksum, Kiai Mahrus Ali, Kiai As'ad Syamsul Arifin, Kiai Ahmad Siddiq dll. Kedua, sebagai pemimpin umat Islam tradisional, keputusan mereka diyakini bukanlah semata-mata berdasarkan pertimbangan politik, melainkan keputusan yang benar-benar berdasarkan keagamaan. Ketiga, sebagai pemimpin umat Islam tradisional, para ulama memahami dinamika terhadap perkembangan dan kebutuhan umat, serta sebagai bantahan terhadap adanya pendapat yang mengatakan bahwa Islam merupakan agama yang konservatif dan kaku, sehingga Islam tidak mampu berkembang dan beradaptasi. Sebagaimana ditegaskan oleh Watt bahwasanya sejarah Islam membuktikan kemampuannya untuk menyesuaikan diri dengan perkembangan :

Jika seseorang melihat dengan seksama kepada sejarah Islam ia akan mendapatkan banyak pristiwa berlangsungnya "adaptasi" itu secara sungguh-sunggug. Perubahanperubahan dalam Islam yang sifatnya adaptif telah terjadi pada masa lalu, sehingga ia akan membenarkan seseorang mengharapkan agar Islam dapat menyesuaikan dirinya dengan persoalan-persoalan masa lalu.

Watt memuji peranan dua orang teolog muslim yang mampu menumbuh kembangkan tradisi Islam (sunni) dalam situasi yang baru, sebagaimana yang dilakukan oleh al-Asy'ari dan al-Ghazali (dua teolog yang sangat berpengaruh dikalangan jamiyah Nahdlatul Ulama). 
Dalam hal ini peranan ijma'(konsesus) sangat besar sekali untuk " mengadaptasikan ajaran dan tradisi Islam dengan situasi baru). Consensus atau persetujuan bersama masyarakat Islam ini, kemudian menjadi kekuatan yang harus diperhitungkan, meskipun konsensus berjalan lamban.

Ada empat agenda dalam Munas 1983 yaitu :

1. Pemulihan NU kepada khittah 1926. NU kembali menjadi organisasi keagamaan dengan mengarahkan program NU kepada situasi pembangunan dan mengatr perangkat organisasi yang mendukung cita-cita NU sesuai khittah 1926.

2. Pemantapan Pancasila sebagai asas organisasi. Dibahas penerimaan Pancasila sebagai asas dan penjabarannya dalam Anggaran Dasar.

3. Penegasan batasan-batasan bagi penyaluran aspirasi politik warga NU melalui kekuatan sosial politik yang ada

4. Pembahasan masalah keagamaan (masail diniyah).

\section{a. Deklarasi Hubungan Pancasila dengan Islam}

Adapun mengenai asas tunggal Pancasila, NU menegaskan dalam deklarasi tentang hubungan Pancasila dengan Islam. Sebagai mana yang tertuang dalam Keputusan Munas alim Ulama NU No.11/MANU/1404/1983 Tentang Pemilihan Khittah NU 1926 yaitu :

1. Pancasila sebagai dasar dan falsafah Negara Republik Indonesia bukanlah agama, tidak dapat menggantikan agama dan tidak dapat dipergunakan untuk menggantikan kedudukan agama

2. Sila Ketuhanan Yang Maha Esa sebagai dasar Negara Republik Indonesia menurut Pasal 29 ayat (1) Undang-Undang Dasar 1945, yang menjiwai silasila lain, mencerminkan tauhid menurut pengertian keimanan dalam Islam.

3. Bagi Nahdlatul Ulama, Islam adalah aqidah dan syari'ah, meliputi aspek hubungan manusia dengan Allah dan hubungan antar manusia.

4. Penerimaan dan pengamalan Pancasila merupakan perwujudan dan upaya umat Islam Indonesia untuk menjalankan syari'at agamanya.

5. Sebagai konsekwensi dari sikap di atas, Nahdlatul Ulama berkwajiban mengamankan pengertian yang benar tentang Pancasila dan pengamalannya yang murni dan konsekwen oleh semua pihak.

\section{b. Landasan Pemikiran NU Menerima Pancasila}

Penerimaan NU terhadap asas tunggal Pancasila tidaklah bermula dari ruang yang hampa. Nahdlatul Ulama memiliki landasan yang kuat dalam menentukan keputusan 
diterimanya Pancasila sebagai asas tunggal yang sudah final. Adapun landasan tersebut adalah :

\section{Konsep Fitrah}

Penerimaan NU benar-benar telah dipikirkan dari sudut pandang pertimbangan keagamaan. Dalam muktamar itu, NU memahami ulang dasar-dasar keagamaannya dan dari sana merumuskan sikapnya terhadap perkembangan yang sedang dihadapi. Dasar-dasar keagamaan paham ahlussunnah wal jama'ah dijabarkan sebagai berikut :

Nahdlatul Ulama mengikuti pendiri, bahwa Islam adalah agama yang fitri, yang bersifat menyempurnakan segala kebaikan yang sudah dimiliki oleh manusia. Paham keagamaan yang dianut oleh Nahdlatul Ulama bersifat menyempurnakan nilai-nilai yang baik yang sudah ada dan menjadi milik serta ciri-ciri suatu kelompok manusia seperti suku ataupun bangsa, dan tidak bertujuan menghapus nilai-nilai tersebut.

Inilah Islam pada hakekatnya menyerahkan diri (self-commitment) sebagai respon terhadap gerak hati yang tertanam di dalam fitrah manusia suatu kedamaian batin yang tidak dapat diperoleh tanpa menemukan Allah dan menyembah Dia.

Secara singkat, Islam tidak terbatas pada manusia saja. Islam mencakup seluruh unsur yang ada, Islam dari segala "sesuatu" dapat secara sukarela atau terpaksa. Tetapi didalam kedua-duanya ia tetap merupakan muslim, karena jika tidak demikian, ia harus berada di luar hal-hal yang ada dan bebas dari segala hukumannya. (Othman, $1981: 3-8$ ).

Fitri atau fitrah merupakan suatu keonsep dalam Islam yang sang penting. Fitrah merupakan dorongan yang sudah tertanan di dalam diri manusia untuk menemukan Tuhan. Dorongan hati (fitrah) itulah yang menyebabkan manusia menyerahkan diri (Islam) kepada Allah. Sebagaimana diungkapkan oleh al-Ghazali, dalam upaya mencapai kebahagiaan manusia selalu terancam oleh " kecintaan terhadap nafsu" yang dapat menghalanginya mengikuti fitrah. Berladaskan hal tersebut al-Ghazali melihat " ada tingkatan-tingkatan dalam Islam yang sesuai dengan tingkat pengetahuan yang dimilikinya (Sitompul, $2010: 176$ ).

Oleh karena itulah, sikap keagamaan NU seperti yang dirumuskan di atas dapat dipahami selalu pola pemikiran al-Ghazali. NU tidak bersikap antithesis terhadap suatu nilai masyarakat. Sepanjang nilai atau sistem dalam masyarakat tidak bertentangan dengan keyakinan Islam, maka ia memiliki potensi untuk diarahkan dan dikembangkan sehingga biasa selaras dengan tujuan-tujuan dalam Islam. Dalam pengertian tersebutlah NU bersikap “ menyempurnakan segala kebaikan yang sdah dimiliki oleh manusia". Begitu juga pandangan al-Ghazali tentang masyarakat yang penting untuk digaris bawahi adalah " bagaimana mengharmoniskan segala aktivitas untuk mencapai kebahagiaan tertinggi atau pemenuhan 
diri (sa'adah). Disinila keberadaan masyarakat yang membutuhkan petunjuk, ajaran, dan rahmat Allah SWT. Dari situlah NU bersikap inklusif, karena mengakui nilai-nilai yang baik yang sudah ada dan akan bersikap kritis konstruktif karena bertujuan menyempurnakan nilainilai tersebut.

Dalam deklarasi tentang hubungan Pancasila dan Islam, menegaskan bahwasana Pancasila bukanlah agama dan tidak bisa menggantikan agama. Keberadaan Pancasila merupakan suatu produk ijtihad masyarakat yang diperlukan guna tercapainya kelestarian dan kedamaian masyarakat. Pancasila dinilai sebagai falsafah bangsa, sedangkan agama adalah wahyu. Sering digunjingkan bahwasanya Islam tidak bisa memisahkan antara agama dan politik. Memang benar NU tidak memisahkan agama dan politik atau agama dengan masyarakat. Akan tetapi ia membedakan mana bidang yang berguna untuk ditanggapi dan mana yang tidak berguna demi tujuan keagamaan. Senada dengan penjelasan al-Ghazali :

Mencari kebenaran meminta sang pencarinya untuk membedakan antara hal-hal dan tujuan yang penting dan perlu yang ada dalam masyarakat dengan hal-hal dan tujuan-tujuan tidak penting dan tidak perlu (Othman, 1981 : 252).

Dalam deklarasi termaktub penerimaan asas Pancasila diputuskan sebagai dasar dan jalan bagi NU untuk menjalankan syari'at (hukum agama) Islam :

Penerimaan dan pengamalan Pancasila merupakan perwujudan dari upaya umat Islam Indonesia untuk menjalankan syari'atnya.

\section{Konsep Ketuhanan}

Nahdlatul Ulama merumuskan Ketuhanan Yang Maha Esa dalam Muktamar Situbondo, sebagaimana termaktub dalam Undang-Udang Dasar 1945 Pasal 29 (1) merupakan ruh yang mampu menjiwai sila-sila selanjutnya dan telah mencerminkan nilai tauhid sebagaimana pengertian keimanan dalam Islam. Negara Pancasila senantiasa disifatkan sebagai jalan tengah dalam memahami Negara agama dan Negara sekuler. Negara membantu mengembangkan kehidupan beragama, akan tetapi keberadaannya tidak mencapuri perjalanan kehidupan internal umat beragama.

Prinsip Ketuhanan yang merupakan pokok perdebatan sengit di antara kalangan nasionalis muslim dan nasionalis sekuler sejak sebelum kemerdekaan diselesaikan secara tuntas oleh NU dengan menyatakan bahwa sila itu mencerminkan ketahuidan dalam Islam. Mencerminkan berarti membayangkan atau mengambarkan suatu perasaan, keadaan batin, dan sebagainya. KH. Ahmad Siddiq pada Muktamar 1984 terpilih sebagai Rais 'Am adalah orang yang boleh dikatakan sebagai konseptor utama keputusan Munas 1983 dan 1984. Ia menjelaskan dalam makalahnya pada waktu Muktamar bahwasanya : 
a. Sila Ketuhanan Yang Maha Esa mencerminkan pandangan Islam akan keesaan Allah, yang dikenal juga dengan sebutan tauhid

b. Adanya pencantuman anak kalimat "Atas berkat rahmat Allah Yang Maha Kuasa" pada pembukaan Undang-Undang dasar 1945, yang menunjukkan kuatnya wawsan keagamaan dalam kehidupan bernegara kita sebagai bangsa.

Pengertian "mencerminkan" tampaknya sudah dipilih secara matang. Tidak disebutkan bahwa itu sesuai dengan ajaran tauhid Islam. Bukankah menyamakan Ketuhanan Yang Maha Esa dengan tauhid dibantah oleh kalangan nasionalis sekuler dan kalangan lainnya yang nonIslam (Sitompul, 2010 : 184). Juga tidak dikatakan bahwasanya hal itu tidak ada kaitannya dengan tauhid dalam Islam. Sebagaimana dijelaskan oleh Imam al-Ghazali dalam tulisanya (Esai Mengenai Jerussalem) yang menjelaskan perjalanan pengembaraannya sebagai seorang sufi yang mencari kebenaran, ia menjelaskan asal mula kepercayaan pada kalangan awam :

Kepercayaan kepada Allah lahir di dalam diri setiap manusia karena fitrahnya (sifat yang ditanamkan Allah ke dalam diri manusia sewaktu menciptakannya), dan tak seeorang pun dapat menghindari dorongan fitrahnya untuk mencari pengetahuan mengenai Allah... Lagi pula, di dalam al-Qur'an kita jumpai banyak sekali “ penanda-penanda" yang dapat berperan sebagai dasar kepercayaan kepada Allah...yang mudah difahami...untuk membuatnya percaya kepada Pencipta Yang Tunggal Yang Memerintah dan Mengendalikan alam semesta (Othman,1981 : 185186).

Selanjutnya al-Ghazali mengenal tingkatan pemahaman akan keesaan Allah sehubungan dengan perkembangan diri agar sampai pada pengenalan yang penuh, sebagaimana kacamata sufisme. Akan tetapi sepanjang untuk orang-orang awam, al-Ghazali sudah puas dengan pemahaman yang sederhana. Pandangan al-Ghazali menegaskan bahwasanya kendatipun Ketuhanan Yang Maha Esa tidak dikatakan identik dengan tauhid bukan berarti terlepas dari penilaian Islam. Penciptaan Allah sangatlah luas dan bisa dikenal dengan ciptaan-Nya. Karena itulah, Islam hanya perlu mengembangkan kefitrahan manusia dan Islam tidak akan menerima suatu Negara sekuler sebab hal itu melepskan suatu bidang dari keagamaann. Islam tidak megengenal pemisahan agama dari politik. Bagi NU yang terpenting adalah Negara dapat menegakkan nilai-nilai keagamaan (Islam) pada semua bidang kehidupan. Sebagaimana ditegaskan oleh Abdurrahman Wahid ketika berbicara tentang kebudayaan. Ia menjelaskan ada dua fungsi yaitu fungsi inspiratif " memberikan kekuatan pendorong" dan fungsi normatife "mengatur dan mengarahkan" kehidupan 
masyarakat (Sitompul, 2010 : 185). Peluang tersebut sudah terbuka didalam Negara Pancasila.

Konsep Islam sebagai suatu yang menyeluruh (ad-Din) adalah konsekwensi logis dari ajaran keesaan Allah (tauhid). Ia adalah konsep bukan idiologi baku yang tinggal diterapkan dalam masyarakat. Dalam pandangan al-Ghazali, Allah tidak menciptakan sesuatu dengan sia-sia, karena apa yang baik dan buruk diukur dari kemanfaatannya dalam kehidupan. Oleh karena itu, wawasan keagamaan NU diperkuat juga oleh UUD 1945 yang memuat anak kalimat “ Atas berkat rahmat Allah “. Memang keberadaan Pancasila itu sendiri bersifat filosofis, akan tetapi apabila diperhatikan rumusan sila pertama dan anak kalimat. Maka Negara Indonesia benar-benar mengutamakan landasan dan wawasan keagamaan bagi kehidupan berbangsa, bernegara, dan bermasyarakat.

Karakter kehidupan bangsa Indonesia yang religious terkamtub dalam UUD 1945 merupakan pengejwantahan dari berbagai tradisi keagamaan bangsa Indonesia. Jika diamati dan difahimi lebih mendalam karakter NU sebagai organisasi keagamaan yang tradisional, menerima tradisi sufistik, maka dengan mudah NU menerima Pancasila dengan mengutamakan landasan keagamaan. Dengan menerima Pancasila berdasarkan pertimbangan teologis seperti diuraikan di atas. Jam'iyah Nahdlatul Ulama telah menegaskan bahwasanya karakter keagamaan sedikit banyak telah memenuhi aspirasi Islam, yaitu segala tingkah laku dalam kehidupan masyarakat baik dalam pengambilan kebijakan akan menjadikan nilai-nilai keagamaan sebagai rujukan.

\section{Pemahaman Sejarah}

Pertimbangan NU menerima Pancasila juga dilatarbelakangi oleh perjalanan sejarah dan peranan umat Islam turut serta memperjuangkan kemerdekaan Indonesia. Sebagaimana pokok pikiran KH. Achmad Siddiq yang dituangkan dalam Muktamar Situbondo. Adapun pokok pikiran tersebut yaitu :

1. Perjuangan Umat Islam Indonesia untuk menolak penjajahan dan memperjuangkan kemerdekaan bangsa dari tangan penjajah telah berlangsung sejak lama.

2. Ketika perjuangan merebut kemerdekaan sudah mendekati keberhasilannya, umat Islam memberikan saham yang sangat besar dalam persiapan lahirnya Negara Indonesia merdeka. Melalui para pemimpinnya, umat Islam ikut menentukan wujud, asas, dan hukum Negara yang akan lahir itu. 
3. Setelah Negara Republik Indonesia diproklamirkan, umat Islam tanpa ragu-ragu membela dan mempertahankan kemerdekaan itu, bukan saja sebagai kewajiban nasional, melainkan juga kewajiban agama.

4. Ketika revolusi fisik telah selesai, umat Islam memberikan saham pula dalam pengisian kemerdekaan yang dicapai dengan penuh pengorbanan itu. Keikutsertaan umat Islam itu terbukti dalam dua jenis kerja besar.

a. Umat Islam berhasil turut menjaga keutuhan Negara dari gangguan gerakangerakan separatis dan pemberontakan-pemberontakan bersenjata.

b. Di era Orde Baru, umat Islam turut mengisi kemerdekaan dalam bentuk partisipasi penuh dalam pembangunan nasional yang sedang berlangsung dewasa ini (Sitompul, $2010: 188$ ).

Perjalanan dan fakta sejarah peranan umat Islam merebut dan mempertahankan tanah Nusantara dari penjajahan sangatlah besar. Uraian ini bukanlah sebagi klaim status politis. Akan tetapi sebagai penegas bahwa keberadaan umat Islam merupakan bagian integral dari perjuangan bangsa. Nilai sejarah terletak dalam pemahaman fakta-fakta yang ada. Dalam rangka nasionalisme, ia dapat menjadi pedang bermata dua; dapat membangkitkan solidaritas dan sekaligus perpecahan, seperti yang terjadi di Dunia Arab modern yang mayoritas beragama Islam.

Penilaian sejarah terletak pada sudut pandang penafsiran dalam memahaminya, tdak jarang adanya penafsiran/pemahaman disesuaikan dengan perkembangan zaman. $\mathrm{KH}$. Achmad Siddiq dengan dalil-dalil hokum Islam (fiqih) memberikan kesimpulan keagamaan, sebagaimana dituangkan pada Mutamar Situbondo. Adapun kesimpulan tersebut yaitu :

a. Mendirikan Negara dan membentuk kepemimpinan Negara untuk memelihara keluhuran agama dan mengatur kesejahtraan kehidupan duniawi wajib hukumna.

b. Kesepakatan bangsa Indonesia untuk mendirikan Negara Republik Indonesia adalah sah dan mengikat semua pihak, termasuk umat Islam.

c. Hasil kesepakatan yang sah itu, yaitu Negara Kesatuan Republik Indonesia adalah sah, dilihat dari pandangan Islam, sehingga harus dipertahankan dan dilestarikan eksistensinya.

d. Sahnya kesepakatan, hasil kesepakatan, dan keterikatan semua pihak itu berlanjut pada hal-hal berikut :

- Kewajiban menurut wujud, asas, dan hukum Negara sebagaimana ditetapkan dalam kesepakatan. 
- Kewajiban menjaga dan mengamalkan asas dalam hokum dasar sebagaimana ditetapkan dalam kesepakatan, berarti kewajiban menjaga agar asas dan hokum dasar itu tidak disimpangkan dan diselewengkan.

- Kewajiban untuk taat kepada penguasa Negara yang sah, dalam hal yang tidak mengajak kepada kekufuran, ingkar kepada Allah, dan pada kemaksiatan yang nyata.

- Kewajiban beramar ma'ruf nahi mungkar (melakukan apa yang diketahui baik dan menjauhi apa yang dibenci Allah) dan saling menasehati, tidak terkecuali kepada pemerintah, menurut cara-cara yang sebaik-baiknya.

- Kewajiban untuk ikut serta secara aktif dan konstruktif dalam upaya mewujudkan tujuan didirikannya Negara.

Dari pendapat-pendapat yang dijadikan dalil untuk kesimpulan keagamaannya, dalam sejarah Islam banyak nama-nama yang terkenal seperti, Abu Hurairah, Ahmad bin Hanbal, Ibn Khaldun dll. Hal ini menunjukkan bahwasanya NU yang claim tradisionalis dalam menanggapi perkembangan social-politik sanggup melakukannya tanpa kehilangan hakikatnya, NU sering dituduh kaku dan lamban. Justru kesetiaan terhadap nilai-nilai tradisi menjadikan NU sanggup merumuskan sikap-sikap keagamaan yang relevan dengan menafsirkan sumber rujukan klasik.

Konsepsi Islam yang universalistik menjadikan NU mempunyai landasan yang sah guna menginternalisasikan diri dengan perkembangan dan sekaligus menyingkirkan sikap yang ingin mendominasi perkembangan. Secara asasi dan asali, berdirinya Negara telah mencerminkan manifestasi aspirasi Islam, kendati Negara itu sendiri tidak berdasarkan Islam, tetapi mempunyai " kewajiban untuk ikut serta secara aktif dan konstruktif dalam upaya mewujudkan tujuan didirikannya Negara.” Karakter NU yang tradisional, dalam arti memiliki sumber refrensi dan rujukan dalam tradisi, membuat NU mampu memilih apa yang terbaik, tetapi sah untuk kelangsungan dan perkembangan Islam dalam situasi yang lebih maju. Mengenai pemahaman sejarah, peran serta umat Islam dalam kehidupan bangsa dan wawasan keagamaan yang dianut oleh Negara, yang dinilai sah menurut Islam. Oleh karena itu KH. Achmad Siddiq menyimpulkan sikap NU yaitu “ Republik Indonesia adalah bentuk upaya final seluruh nation teristimewa kaum muslimin untuk mendirikan Negara di wilayah Nusantara”. Oleh karena itulah, penerimaan NU atas asas Pancasila ditegaskan dalam anggaran Dasar jam'iyah Nahdlatul Ulama. NU menerima “ panjang-lebar”, menerima dengan sikap positif, menerima dalam rangka perjuangan bangsa dan Negara untuk mencapai 
masyarakat yang adil dan makmur. Dan penerimaan Pancasila sebagai asas tunggal yang sudah final dimuat dalam muqodimah Anggaran Dasar Jam'iyah Nahdlatul Ulama.

\section{Penutup}

Perjalanan panjang sejarah berdirinya Negara Indonesia pada saat memproklamirkan kemerdekaan, terdiri dari berbagai komunitas yang bersatu padu, menyusun kekuatan bersama untuk mendirikan sebuah Negara yang merdeka dan berdaulat. Tekat bulat untuk menentukan masa depan tersebut didorong oleh suatu kekuatan besar yang dilatarbelakangi alam pikiran yang memadahi. Begitu juga halnya dengan peranan umat Islam dalam perebutan kemerdekaan tidaklah bisa dipandang sepele.

Fakta sejarah telah menjelaskan, bagaimana peranan umat Islam khususnya warga NU dalam upaya mengkonsolidir kekuatan melakukan perlawanan terhadap hegemoni yang dilakukan oleh para penjajah dengan menggunakan kekuatan fisik dan kultural. Sampai pada pembentukan idiologi Negara yang mengalami perdebatan sangat panjang. Jam'iyah Nahdlatul Ulama memiliki tanggungjawab besar dalam melakukan pengawalan kemerdekaan Indonesia. Hal ini menjadi bukti bahwasanya komitmen Jam'iyah Nahdlatul Ulama dalam membentengi bangsa Indonesia tidak akan lekang dimakan waktu.

Pasca kemerdekan, para pendiri bangsa mengalami perdebatan panjang dalam penentuan idiologi Negara yang mampu menampung dan mengayomi seluruh kepentingan rakyat Indonesia. Ketika ditetapkannya Pancasila sebagai asas tungal yang sudah final. Maka, Jam'iyah Nahdlatul Ulama mengambil sikap dengan tegas penerimaan Pancasila sebagai Idiologi Negara Republik Indonesia dengan melakukan diskusi panjang dan mengambil rujukan kitab klasik sebagi dasar pengambilan keputusan tersebut.

Dengan perjalanan waktu, idiologi bangsa Indonesia mengalami cobaan yang berat baik gempuran dari luar maupun dari dalam Negeri. Pergulatan panjang penentuan Pancasila sebagai idiologi Negara yang dilakukan oleh para pendiri bangsa, seolah-olah tinggal wacana dan cerita saja. Implementasi nilai yang terkandung dalam Pancasila mengalami pengaburan dan terjadi kemosrotan tajam dikalangan rakyat Indonesia. Terjadinya fenomena khilafah menjadi ancaman tersendiri bagi bangsa Indonesia. Belum lagi nilai-moral Pancasila yang tidak teraktualisasikan dengan baik dalam perjalanan kehidupan rakyat Indonesia, sehingga terjadi tindakan korupsi stuktural yang dilakukan oleh para wakil rakyat, keadilan yang belum berpihak, terorisme yang menghantui kedamaian dan kenyamanan rakyat, pembunuhan antar anak bangsa, bentrokan antar warga yang tidak kunjung berakhir.

Oleh karena itu, marilah kita bermuhasabah merefleksikan jati diri kita sebagai anak bangsa. Menanamkan kembali nilai-nilai moral Pancasila sebagai pedoman dalam 
menjalankan kehidupan berbangsa dan bernegara dengan baik. Janganlah selalu menyalahkan Pancasila dan ingin mengubahnya dengan idiologi yang berbeda. Pancasila adalah asas tunggal yang final dan harus dipertahankan sampai titik darah penghabisan. Pancasila tidak akan memiliki makna yang signifikan, apabila kita sebagai anak bangsa tidak memahami filosofi dan nilai moral yang ada dalam diri Pancasila, serta mengimplementasikan dalam kehidupan sehari-hari.

\section{DAFTAR PUSTAKA}

Boland. J. B. 1971. The Stuggle of Islam in Modern Indonesia. The Hague : Martinus Nijhoff. Harun, Lukman. 1986. Muhamadiyah dan Asas Pancasila. Jakarta : Pustaka Panjimas.

Irsyam, Mahrus. 1984. Ulama dan Partai Politik. Jakarta : Yayasan Perkhidmatan

Karim, M. Abdul. 2005. Islam dan Kemerdekaan Indonesia, Membongkar Marjinalisasi Islam Dalam Perjuangan Kemerdekaan RI. Yogyakarta : Sumbangsih Pres.

Karim, M. Rusli. 1983. Perjalanan Partai Politik di Indonesia. Jakarta : Rajawali Press.

Latif, Yudhi. 2011. Negara Paripurna, Historisitas, Rasionalitas, dan Aktualitas Pancasila. Jakarta : Gramedia.

Ma'arif, Ahmad Syafi'i. 1985. Islam and Nationalism in Indonesia. Bandung : Mizan.

Murtopo, Ali. 1978. Strategi Kebudayaan. Jakarta : Yayasan Proklamasi

Oppenheimer, S. 2010. Eden in the East, Benua yang Tenggelam di Asia Tenggara. Jakarta : Ufuk.

Othman, Issa, Ali. 1981. Manusia Menurut Al-Ghazali. Bandung : Pustaka.

Pranarka, A. M. W. 1985. Sejarah Pemikiran Tentang Pancasila. Jakarta : ICIS.

Ridha, al-Sayid Muhammad Rasyid. 1373 H. Tafsir al-Qur'an al-Hakim / Tafsir al-Manar. Jilid V. Mesir : Maktabah al-Qur'an.

Sitompul, Martahan,Einar. 2010. NU Pancasila. Yogyakarta : LKiS. 